\title{
THE CONCEPT OF SMART CONTRACTS FROM THE LEGAL PERSPECTIVE
}

\author{
Karolina Kasprzyk*
}

\begin{abstract}
The purpose of article hereof is to introduce the significant characters of the smart contracts and certain ideas and proposals de lege ferenda on regulatory framework for smart contracts. Furthermore, present legislation with regard to the legal definition of the smart contract will be discussed from a comparative perspective. Particular note will be devoted to smart contracts in a relation to the contract law. Substantively, legal issues arising from the use of smart contracts, focussing upon actual and potential conflicts with established principles of contract law, will be introduced.
\end{abstract}

Key words: smart contracts; blockchain; automation of law; contractual relations; crypto-property;

\section{INTRODUCTION}

Over the last few years, we have been witnessing the constant development of technical tools within the scope of data transfer, the speed of its processing and the widespread availability of mobile devices and applications. The digital revolution concerns decisively various areas of social and economic relations, not excluding legal relations. One of the most disruptive digital technologies, in relevance with law is blockchain. Blockchain was first introduced as the core technology behind bitcoin, the head-

* Ph.D. candidate, I Department of Civil Law, Faculty of Law, Canon Law, and Administration at the John Paul II Catholic University of Lublin. 
line-grabbing decentralized digital currency ecosystem proposed in $2008^{1}$. A blockchain is a continuously growing distributed database that protects against tampering and revision of data and has the potential to shapeshift the nature of today's economic processes. As indicated, blockchain technology was first introduced for peer-to-peer bitcoin payments, but more recently, it has been used more broadly. One significant novel use for blockchain is to enable smart contracts ${ }^{2}$.

\section{THE CONCEPT OF SMART CONTRACTS}

The concept of smart contracts was initially introduced by the computer scientist and legal scholar Nick Szabo in 1994. Nevertheless, it is worth to emphasize that the idea of smart contract has been around before. The prototype of the deployment of smart contract is the vending machine. The machine itself represents the offer. When someone inserts money into the machine, acceptance of that offer occurs, then a contract is formed and performance (transfer ownership of a drink or a snack) automatically takes place. The vending machine executes and enforces the smart contract, even without application of particularly sophisticated technology $y^{3}$.

In the initial N. Szabo's essays, Author convinced that the digital revolution challenges society to develop new institutions in a much shorter period of time. The drawing fourth current laws, procedures, and theories those principles which remain applicable in cyberspace, facilitate preservation of this affluent tradition, and significantly reduce the time needed to

1 Gupta S., The Management Accountant. The Journal for CMAs. Block chain Technology, June 2018, Vol 53, No 6, p. 6, http://icmai.in/upload/Institute/Journal/Journal_June_2018.pdf, [date of access: 18.11.2018].

2 Luu L., Chu D. H., Olickel H., Saxena P., Hobor A., Making smart contracts smarter. In Proceedings of the 2016 ACM SIGSAC Conference on Computer and Communications Security. ACM, p. 254.

3 Schneider L., Evans J., Kim A., Why blockchain smart contracts matter. International Financial Law Review, London (Feb 27, 2018), https://search.proquest.com/ docview/2020422359?accountid=11796, [date of access: 27.11 .2018 ]. 
develop useful digital institutions. Computers enable the operation of algorithms that have been excessively expensive so far, and connect networks of larger and more sophisticated messages. In addition, computer scientists and cryptographers have lately discovered new types of algorithms. Combining these messages and algorithms allows to use wide range of original protocols. These protocols, operating in public networks such as the Internet, enable to formalize and secure new types of relationships in this new milieu, e.g. contract law, business forms and accounting controls which have for long formalized and secured business relationships in the reality based on traditional, paper documents. Automation of the implementation of business relations requires the cooperation of two separate areas, such as economics and cryptography. The development of criteria relevant to each of these domains, aims at achieving common sakes and corresponds with the concept of smart contracts 4 .

According to N. Szabo, a smart contract is a computerised transaction protocol that implements the terms of the contract. With regard to another recently enunciated definition, a smart contract is "a set of promises, specified in digital form, including protocols within which the parties perform on these promises". In general, in that context, a smart contract is a machine-readable program, recorded in a source code that will execute itself when a set of pre-determined terms are met. Thus, smart contracts are self-executing protocol designed to allow for the exchange of digital goods or services ${ }^{7}$. Applications designed with smart contracts challenge to revolutionize plenty of business and industries brunches (e.g. finance, logistics, insurance sector and payments).

4 Szabo N., Formalizing and Securing Relationship on Public Networks, First Monday Peer-Reviewed Journal on the Internet, Vol. 2, No 9, 1997,, https://firstmonday.org/ article/view/548/469, [date of access: 3.12.2018].

5 Kölvart M., Poola M., Rull A., Smart Contracts, In: The Future of Law and eTechnologies, ed. Kerikmäe T., Rull A., Springer 2016, p. 133.

6 Lauslahti K., Mattila J. \& Seppälä T., Smart Contracts - How will Blockchain Technology Affect Contractual Practices?, ETLA Reports, January 2017, No 68, https:// pub.etla.fi/ETLA-Raportit-Reports-68.pdf, [date of access: 3.12.2018].

7 Weber R. H., "Rose is a rose is a rose is a rose" - what about code and law?, Computer Law \& Security Review 34 (2018), p. 704. 
In addition, M. Kólvart, M. Poola and A. Rull identified smart contract as "an intelligent agent" which is a computer program capable of making decisions when certain preconditions are $\mathrm{met}^{8}$.

Some of the authors identify smart contracts as a computer program (a piece of computer code) that enable to execute predefined terms. Contrary, some of them, define smart contracts as the contract binding parties entering into, in its legal sense. It is noteworthy, that the concept of smart contract is understood differently by representatives of various sciences. IT scientists identify smarts contracts as automatic protocols that substitute traditional paper-based contracts, concluded and performed without referring to any jurisdiction and applicable law. However, that statement seems to be oversimplifying. The legal nature of a certain contract depends on a numerous factors, therefore, it cannot be presumed a priori that it is not a contract, admittedly expressed in a specific formula, but still a contract'.

Apart from above mentioned, key question arises: whether smart contracts are legally relevant?

N. Szabo believed that smart contracts are applicable in all contractual phases of contract: search, negotiation, commitment, performance, and adjudication ${ }^{10}$. Smart contracts use protocols and users' interfaces to deploy all stages of the contracting process. These allow to implement new unstandardized ways for formalization and securing digital relationships, far more functional than forgoing paper based instruments ${ }^{11}$. N. Szabo clarified that: "The basic idea behind smart contracts is that many kinds of contractual clauses (such as collateral, bonding, delineation of property rights, etc.) can be embedded in the hardware and software we deal with, in such a way as to make breach of contract expensive (if desired, sometimes prohibitively so) for the breacher" ${ }^{\prime 2}$. Referring to the above mentioned statement, smart contract are functionalities set to minimalize transaction cost arising from inter alia, conclusion, breach, default or enforcement ${ }^{13}$.

\footnotetext{
8 Kólvart M., Poola M., Rull A., op. cit., p. 134.

9 Szostek D., Blockchain a prawo, Warszawa, C.H. Beck, 2018, p.116.

10 Szabo N., op. cit.

11 Szostek D., op. cit., p. 113-114.

12 Szabo N., op. cit.

13 Trüeb H. R., Smart Contracts, In: Festschrift für Schnyder A. K., ed. Grolimund P., Leander A.K., Loacker D., Portmann W., 2018, p. 703.
} 
From a legal perspective, a contract is an agreement between parties giving rise to a binding legal relationship or some other legal effect. Smart contracts are seen as the new forms of arrangements which are similar to contracts and which are written in a source code ${ }^{14}$. It is noteworthy, that smart contracts are contracts whose terms are recorded in a computer language instead of legal language ${ }^{15}$. A smart contract by itself is not a legal contract. It may become a legal contract if it meets the requirements of contract law. Consequently, parties of a smart contract can correspond to a legal contract or a clause in a legal contract, but they do not have to ${ }^{16}$. Undoubtedly, certain minimum criteria must be met to conclude a legal contract. A "legal" smart contract shall concluded when parties intend to be legally bound and they reach a sufficient agreement without any further requirement ${ }^{17}$. The specific principles of contract law shall provide for conclusion of "legal" smart contract. If smart contracts are capable to take into account the legal provisions applied to contracts formation, then smart contracts can attain effects of legal contracts. Even if these contracts are expressed in highly specialized programming language, content of the smart contracts can encode any processing logic possible to express in the used language in a precise and unambiguous manner ${ }^{18}$.

Adjudication the legal character of smart contracts is the fundamental subject matter over the discussion on the smart contracts. Shall be noted that smart contracts are not only managed by their programming logic or the code they are developed, but they are inextricably also influenced by the state of the law ${ }^{19}$. It is now considered that, new legal niches arises.

14 Kölvart M., Poola M., Rull A., op. cit., p. 136.

15 Distributed Ledger Technology: beyond block chain. A report by the UK Government Chief Scientific Adviser, p.18, https://assets.publishing.service.gov.uk/government/ uploads/system/uploads/attachment_data/file/492972/gs-16-1-distributed-ledger-technology.pdf, , [date of access: 15.12.2018].

16 Idelberger F., Governatori G., Riveret R., Sartor G., Evaluation of logic-based smart contracts for blockchain systems. In International Symposium on Rules and Rule Markup Languages for the Semantic Web. Springer, 2016, p. 169.

17 Kólvart M., Poola M., Rull A., Smart Contracts, op. cit., p. 136.

18 Guarnizo J., Szalachowski P., PDFS: Practical Data Feed Service for Smart Contracts, 2018, https://arxiv.org/pdf/1808.06641.pdf, , [date of access: 18.12.2018].

19 Lauslahti K., Mattila J. \& Seppälä T., op. cit. 
Some authors indicate that a new discipline is being created among lawyers combining the law with cyberspace, legal programming, that is the integration of computer science with the law ${ }^{20}$.

In the subsequent part of this contribution, a few comments shall be devoted to reviewing current legislation to the extension of smart contracts and evaluating de lege ferenda proposals relative "legal" smart contracts. Then, it shall be discussed, if the general legal doctrines of Polish contract law are applicable to the smart contracts. Further, whether smart contract may confer rights or obligations on its parties as the source of legal relation. Ultimately, which specific conditions shall be meet to classify the smart contract as the "legal" smart contract.

Nevertheless, at this point, technical facets as the significant aspect of functioning the smart contracts, shall be present.

\section{TECHNICAL ASPECTS - SMART CONTRACTS' MECHANISMS ON BLOCKCHAIN}

As it was mentioned above, smart contracts have been linked to the blockchain technology. Particularly, smart contracts may be stored in blockchain or another distributed ledger technology, as well as by using another functionalities ${ }^{21}$. Admittedly, the contribution hereof is not devoted to blockchain, nonetheless, it shall be address some technical aspects functioning of the blockchain, as it is the common technology for stored smart contracts. The blockchain is a database which is private, decentralized and denationalized ${ }^{22}$. Therefore, blockchain constitute the platform designed appropriately for enforcement of smart contracts, free from government or central financial institutions' influence. Blockchain is seen as a distributed database for independently verifying the chain of ownership of digital property ${ }^{23}$. Particularly, blockchain comprises of distributed, decentralized

20 Shcherbak S., Integrating Computer Science into Legal Discipline: The Rise of Legal Programming (September 14, 2014); December 18, 2018, https://papers.ssrn.com/ sol3/papers.cfm?abstract_id=2496094.

21 Szostek D., op. cit., p. 126.

22 Trüeb H. R., Smart Contracts, op.cit., p. 705.

23 Kólvart M., Poola M., Rull A., op.cit., p. 144. 
transaction ledgers operated and supported in a peer-to-peer ecosystem and then stored in each node (which is operated by users, so called miners) ${ }^{24}$. Every single transaction is assorted in blocks which are later hashed (accord with a specific cryptographic fingerprint) in pairs and then incorporated in the chain of prior blocks ${ }^{25}$. Each block in the chain exports a list of transaction and the hash of the previous block ${ }^{26}$. This creates a link between the blocks, in the sequel, creating a chain of blocks. Every user of chain of block is eligible to observe general description of the information transferred by block, but is deprived to access that certain block which is encrypted. The significant feature of blockchain technology, is that any block shall not be delated, thus the components of the chain, its blocks, are perpetual. Consequently, there is no possibility to defraud the blockchain.

A smart contract stored in blockchain can encode complex set of rules codified in its programming language, e.g. a contract can execute transfers when certain circumstances are met, following the logic: "if this, then that" (e.g. payment of security deposits in an escrow account). From the technical point of view, a smart contract is identified by an address (a 160bit identifier) and its code remains on the blockchain. Commonly, users launch a smart contract in cryptocurrencies by sending transactions to the contract address. In particular, "if a new transaction is accepted by the blockchain and has a contract address as the recipient, then all participants on the mining network execute the contract code with the current state of the blockchain and the transaction payloads as inputs" ${ }^{27}$. The network then agrees on the output and subsequent status of contract by attending in a consensus protocol. The sake of the consensus mechanism within a blockchain is to remain a unified record for of all transactions. The consensus shall be reached by distinct methods. One of the method is the use by blockchain platform the proof of work mining protocol for network consensus ${ }^{28}$. The

24 Trüeb H. R., op.cit., p. 705.

25 Trüeb H. R., op.cit., p. 705.

26 Christidis K., Devetsikiotis M., Blockchain and smart contracts for the Internet of Things, In: IEEE Access 4 (2016), p. 2293.

27 L. Luu, D. H. Chu, H. Olickel, P. Saxena, A. Hobor, op.cit., p. 254.

28 Hu Y., Liyanage M., Manzoor A., Thilakarathna K., Jourjon G., Seneviratne A., Ylianttila M., The Use of Smart Contracts and Challenges, 26 Sep 2018, https://www. researchgate.net/publication/328230865, [date of access: 16.12.2018]. 
proof of work facilitates the $51 \%$ of users to alter the blockchain democratically and unilaterally ${ }^{29}$.

As it was mentioned before, smart contracts are structured by piece of code. The process of codifying them, involves a certain components: the source code, the wallet, the storage file and the register ${ }^{30}$. Code incorporates particulars of the intended transaction. The transaction characterises the transfer of an information, establishing the smart contract. Then, the wallet is a digital expanse where cryptographic keys are stored. More generally, two types of keys shall be differentiate. The private one, that enables the user admission to crypto-property and entitled to control his account ${ }^{31}$. Whereas, the public key authenticates user's messages, then encrypts them. The storage file is a digital space where a transaction is hold by the time it is registered ${ }^{32}$. Ultimately, the register is the place for transactions' storage, mostly in blockchain system.

Due to the process of verification of each transaction through the nodes and then sending stored contract to each node, execution of smart contract is automatic. It enables the "digitization of trust through certainty of execution" and the assurance of effectiveness among removal intermediaries ${ }^{33}$. Transactions conducted on blockchain can be automatically triggered when a certain conditions are met, and this is achieved with smart contracts that enable users to enter into mutual agreements with each other ${ }^{34}$. Due to the

29 Jaccard G. O. B., Smart Contracts and the Role of Law, In: Jusletter IT, 23 November 2017, https://papers.ssrn.com/sol3/papers.cfm?abstract_id=3099885, [date of access: 18.12.2018].

30 Essebier J., Wyss D.A., Von der Blockchain zu Smart Contracts, in: Jusletter, 24 April 2017, https:/www.vischer.com/fileadmin/redaktion/Dokumente/publikationen/ fachpublikationen/JES_DOWY_Jusletter_Blockchain_04_2017.pdf, [date of access: 10.12.2018].

31 Jaccard G. O. B., op.cit.

32 Jaccard G. O. B., op.cit.

33 Durovic M., Janssen A. The Formation of Smart Contracts and Beyond: Shaking the Fundamentals of Contract Law?, In: Smart Contracts and Blockchain Technology: Role of Contract Law", eds. DiMatteo L., Cannarsa M. \& Poncibo C., Cambridge University Press 2019) (forthcoming), https:/www.researchgate.net/publication/327732779, [date of access: 21.12.2018].

34 Hu Y., Liyanage M., Manzoor A., Thilakarathna K., Jourjon G., Seneviratne A., Ylianttila M., op. cit. 
fact, that the smart contracts' mechanism is automatic, the risk of non-performance is minimalised ${ }^{35}$. In addition, as the code constructing the smart contract is immutable, no one could intervene in codified terms and change them. Notwithstanding, with respect to the immutableness of the codified terms, there is a limited level of interactivity, thus there is no option for parties to negotiate and amend terms agreed heretofore ${ }^{36}$. It is noteworthy, that some authors note that it is possible to provide flexibility on the conditions of smart contracts, under certain circumstances. G. Jaccard stated: "However, a smart contract is not immutable in all conceivable scenarios. (...) firstly, the Blockchain might be forked by a majority of users. And second, the computer code of the smart contracts can contain several functions that enable a certain range of flexibility. For instance, we can mention functions as "callcode", "enums", "selfdestruct", and also variable functions enabling the smart contract to process external inputs" 37 .

Summarise, smart contract shall be described as a computer code enforcing rules and consequences. The program particularly enables the automation of legal content with regard to sequence "if this, then that". The infrastructure behind the smart contracts is as follows: the blockchain, as the register where smart contracts are stored and crypto-property is recorded. Thereafter, the crypto-property as the value that is transferred. Followingly, the smart contract, instrument that determine all the conditions for the transfer of crypto-property.

\section{LEGAL REGULATIONS ON SMART CONTRACTS - COMPARATIVE VIEW}

The potential of smart contracts functionalities based on the blockchain technology, has been esteemed not only by the IT professionals or legal researchers. Recently, smart contracts become subject of the legal regulations, becoming part of legislation.

35 Trüeb H. R., op. cit., p. 707.

36 Y. Hu, M. Liyanage, Manzoor A., Thilakarathna K., Jourjon G., Seneviratne A., Ylianttila M., op. cit.

37 Jaccard G. O. B., op. cit. 
The complex legal definition of smart contracts was introduced in Virtual Financial Assets (VFA) Bill adopted by Parliament of Malta on 5 July, $2018^{38}$. In Article 2. (2) smart contract was defined as: "a form of technology arrangement consisting of: (a) a computer protocol; or (b) an agreement concluded wholly or partly in an electronic form, which is automatable and enforceable by computer code, although some parts may require human input and control and which may be also enforceable by ordinary legal methods or by a mixture of both".

It seems that definition hereof most closely reflects the essence of smart contracts, with regard to the complexity of the commented phenomenon into legal framework.

The definition of smart contract was also introduced in Decree of the President of the Republic of Belarus, No. 8, adopted on 21 December 21, $2017^{39}$. According to the definition, designated in Annex No. 1 to the Decree "List of used terms and their definition", smart contract is "program code intended for functioning in the transaction block ledger (blockchain), another distributed information system for purposes of automated performance andlor execution of transactions or performance of other legally significant actions".

Additionally, the legal definition of smart contract was introduced in Act amending Title 44, Chapter 26 Arizona Revised Statutes by adding Article 5; relating to electronic transactions ${ }^{40}$. In accordance with that Act, smart contract means "an event-driven program, with state, that runs on a distributed, decentralized, shared and replicated ledger and that can take custody over and instruct transfer of assets on that ledger". The Act hereof also defines the term blockchain. Furthermore, the Act states that smart contracts are enable to use in economic relations, they shall not be denied legal effects, validity or enforceability only because they contain intelligent instructions. It is recognized that data secured by blockchain technology is equivalent to other data protected in an alternative system. The rule does not apply solely to contracts providing for the transfer of rights of ownership or use.

38 http://www.justiceservices.gov.mt/DownloadDocument.aspx?app=lp\&itemid= 29079\&l=1, [date of access: 18.12.2018].

39 http://law.by/document/?guid=3871\&p0=Pd1700008e, [date of access: 18.12.2018].

40 https://legiscan.com/AZ/text/HB2417/id/1497439, [date of access: 12.12.2018]. 
In Polish legal system, currently there is no specific legal framework on smart contracts, that directly concern them or on the basis of which its specific normative qualification shall be made. It should therefore be stated that the mere use of blockchain and smart contract functionalities, in legal transactions is fully legal, as the legislation does not differentiate the legal status of these functionalities, in accordance with the principle of quod lege non probibitum, licitum est ${ }^{41}$.

Analysis and research study performed by "Strumień Blockchain i kryptowaluty" as a part of government program "Od papierowej do cyfrowej Polski" demonstrates that there is no justification for framing proposals or adopting initiatives on creating separate legal act dedicated to blockchain or cryptocurrencies. Nonetheless, it is not excluded that such need may arise in the future - it will depend on the detailed forms applications of these technologies and the degree of their dissemination in the society ${ }^{42}$. Simultaneously, there is propound for introduction of the so-called "regulatory sandbox" which are legal arrangements enable start-up entrepreneurs to continue research and development initiatives and implementation of functionalities based on the blockchain technology.

W. J. Kocot suggests to commence preliminary works on statutory regulations of general principles of using decentralised database technologies in the process of concluding and implementing self-executed automated smart contracts. Among the estimated legal regulations, shall be introduced the minimum requirements for algorithms installed in operating systems of devices based on adaptive software, the obligation to update them and protection against unauthorized modification or interference. According to the Author, it is indispensable to confer on smart software legal personality by means of an entry into the publicly available electronic register along with the indication of the authorship (programmer) and as-

${ }^{41}$ Hulicki M., Lustofin P., Wykorzystanie koncepcji blockchain w realizacji zobowiązań umownych, In: Człowiek w cyberprzestrzeni, No 1/2017, p. 41.

42 Zacharzewski K., Piech K. (ed.), Przegląd polskiego prawa w kontekście zastosowań technologii rozproszonych rejestrów oraz walut cyfrowych. Stanowisko Strumienia w sprawie kierunków ewentualnych prac legislacyjnych oraz działań regulacyjnych instytucji publicznych, 19.01.2017, p. 12, https:/www.gov.pl/documents/31305/52168/przeglad_polskiego_prawa_w_kontekscie_zastosowan_technologii_rozproszonych_rejestrow_oraz_walut_cyfrowych.pdf/f6e74ce0-09e5-776d-bd3b-c21fca96cce2, [date of access: 27.11.2018]. 
signing to a person or group of persons authorized to use it (beneficiaries)., which shall facilitate the identification of an indirectly responsible entity for their actions or negligence, and would also support to control over the turnover of such software ${ }^{43}$.

\section{LEGAL RELEVANCY ON SMART CONTRACTS}

The significant element of Polish contract law rules is the declaration of will. The entire Polish Civil Code is based on declarations of will. As well as, that involves legally relevant actions, because an action (e.g. the transfer of an object, the transfer of an amount of money) only has legal effect if it is based on the legal will that these actions constitute a legally relevant action ${ }^{44}$.

Article 60 of the Civil Code introduces a legal definition of a declaration of will, according to which the behaviour of a person who performs a legal act reveals his will in a sufficient manner. This definition is not complete without referring to the concept of a legal action. The declaration of will is solely behaviour aiming trigger an effect in the form of creating, changing or terminating the legal relationship, that is behaviour that is to influence the existence and content of civil rights and obligations ${ }^{45}$.

In the latest Polish legal literature, the declaration of will is referred to as a conventional activity ("a sign"), regulating the legal situation of the entities concerned, and therefore intentionally addressed to other entity. It should be determined, when an entity's act shall be qualified as its declaration of will, which is a condition of occurrence of legal effects related to a statement about a given content. Such assignment is possible if the effects are actually realized by the person submitting the statement . It is

43 Kocot W. J., Kontrakty kreatywne - nowy rozdział w cyberrewolucji prawa umów, In: Experientia docet. Księga jubileuszowa ofiarowana Pani Profesor Elżbiecie Traple, ed. Kostański P., Podrecki P., Targosz T., Warszawa, 2017, p. 960.

44 Furrer A., The embedding of smart contracts into Swiss Private Law, https://www. mme.ch/fileadmin/files/documents/MME_Compact/2018/1803_Smart_Contracts_Furrer.PDF, [date of access: 27.11.2018].

45 Gniewek E., Machnikowski P. ed., Kodeks cywilny. Komentarz, wyd. 7, Warszawa 2016 , p. 146. 
noteworthy, that the awareness of the effect of legal consequences is not a necessary condition of attributing a declaration of will to the person. This is possible, when the behaviour of the entity evokes for others a reasonable belief that the entity is seeking to have legal effects. Described conception of a declaration of will has the value of universality, it shall also applied to declarations of will made in electronic form (even in an automated manner). That observation is significant for issue of legal relevancy on smart contracts.

Regardless of the adopted conception, it shall not be subject of any controversy, that statements generated and submitted automatically are declarations of will within the meaning of Article 60 of the Civil Code. Such a declaration shall not be deprived of effectiveness and probative power, only for the reason that it is created and submitted in the form of an electronic document in a one-sided or bilaterally automated manner" ${ }^{\text {}}$.

Law provides that the conclusion of a contract requires a mutual expression of intent of the parties. The expression of intent may be express or implied. The significant element of the contract is the compliance of statements (consensus), not compliance of internal will of the parties. Therefore, the contract does not conclude if there is no such agreement (dyssens) ${ }^{47}$.

Article $353^{1}$ of the Civil Code establishes one of the fundamental rules of Polish civil law - the rule of the freedom of a form of declarations of will. It provides that the declaration of will shall express by any behaviour, underlying that the law shall provide exceptions to the rule. Provisions of Article 73 and Article 76 of the Civil Code, determine the annulment of action due to the failure of compatibility of the form, only if the particular form was stipulated for a certain activity (by the statute or by the parties $)^{48}$.

Primary, due to the scope of the use in the market, detailed regulated in the Civil Code, way of entering into contract is, offer and its acceptance ${ }^{49}$. It is noteworthy, that the mutual parties' consent is generally materialized

46 W. J. Kocot op. cit., p. 948.

47 Wolter A., J. Ignatowicz, Stefaniuk K. ed., Prawo cywilne. Zarys części ogólnej, Warszawa, 2001, p. 258.

48 Gniewek E., Machnikowski P. ed., op. cit., p. 611.

49 Wolter A., Ignatowicz J., Stefaniuk K. ed., op. cit., s. 291. 
by an offer submitted by one party which is accepted by the another one. Substantively, the offer must include all essential elements of the contemplated contract outlining the intent of its author as legally binding in case of acceptance. An incomplete acceptance of the essential terms of the offer would not form a binding contract, but constitutes a mere counter-offer which would need to be accepted ${ }^{50}$.

In order to establish a legally binding smart contract, the essential elements of the proposed contract must be clearly spell out in the compute program, be sufficiently precise, clear and understandable to be validly accepted by all parties ${ }^{51}$.

Questionable with a smart contract may be that the parties do not always follow the traditional offer-acceptance mechanism as the intent of the parties is rather included in their actions: one party creates the smart contract and transfer certain (digital) assets on the contract while the other party acts in accordance with the terms of the contract. Consequently, the other party accepts the offer without an explicit declaration of intent. Accordingly, even if one can argue that there is no explicit declaration of intent using smart contract, the behaviour of a party would be sufficient to determine its intent based on the execution of the transaction ${ }^{52}$. Therefore, in some cases, a smart contract may be considered valid with regard to all facts and circumstances as well as the conduct of the parties.

It was above mentioned that, there is a rule of the freedom of a form of declarations of will. Nevertheless, some contracts are required by law provisions to be express in a certain form, e.g. in writing, and thus would not be valid under law if they were only registered using the blockchain technology. Therefore, enforceability of smart contracts shall be assess from the perspective of the form requirement determined by law. Effectively, contracts in general, are not subject to specific forms of contract by law ${ }^{53}$.

50 Derungs L. E., Küng Ch. ed., Data, Blockchain and Smart Contracts - Proposal for a robust and forward-looking Swiss ecosystem, Regulatory Task Force Report Swiss LegalTech Association (SLTA), 27 April 2018, p. 42, https://www.swisslegaltech.ch/ wp-content/uploads/2018/05/SLTA-Regulatory-Task-Force-Report-2.pdf, [date of access: 27.11.2018].

51 Derungs L. E., Küng Ch. ed., op. cit.

52 Derungs L. E., Küng Ch. ed., op. cit.

53 Derungs L. E., Küng Ch. ed., op. cit. 
Some also note, that it is complicated to determine how one could prove the transaction entered into by using blockchain technology, in case of litigation. Whereby, the question arises: would a simple print of the code line be sufficient to be recognizable as a valid proof by the judge?54.

Conclusively, in the event of establishing smart contract, parties shall accord to use the smart contracting functionalities to implement the contract terms, otherwise, smart contracting is not part of the legal contract and therefore not legally binding. Smart contract is legally binding only if parties have agreed upon all essential requirements needed for the conclusion of the contract in its legal sense $e^{55}$.

\section{SUMMARY}

The concept of the smart contracts has been unexplored for years. Nevertheless, with the tremendous rise of the blockchain technology, smart contracts seem to be finally implemented in a practical way. The question about the actual legal effects of smart contracts is becoming increasingly, especially due to the fact that smart contract applications relevant to industry and economics, including financial sector, are deploying. The accrual development of the devices for automation of the processes, also transforms the established models of concluding the contracts. As it was clarified, smarts contracts are computer codified protocols that fulfil certain assignments, e.g. transferring digital data or property. Smart contracts are used aside legal contracts to automatically implement the terms of legal contracts. Therefore, smart contract is not a legal contract by itself. For establishing smart contract as the legal smart contract, certain circumstances shall be met. Above all, a mutual expression of intent of the parties to the contracts shall be required. The intention of the parties to be in a legally binding contractual relationship, has to be determined by the offer and its acceptance. Consequently, smart contracts may be legally relevant only if the contracting terms are in compliance with the principles of contract law. Legislators, as well as law practitioners face some challenges

54 Derungs L. E., Küng Ch. ed., op. cit.

55 Kôlvart M., Poola M., Rull A., op. cit., p. 139. 
associated with the legal recognition of smart contracts as conventional contracts, with regard to their specific character and distinctions between them and traditional contracts. The significant characteristics of smart contracts enable to increase the speed of performance of parties' contractual obligations. Blockchain technology ensures transparency, reliability, and security of the performance of smart contract. For this reason smart contracts have the potential to be applied in sectors where trust is involved between market participants. Using smart contracts involves reducing the cost of contracting, and then litigation costs. Additionally, smart contracts minimalize the risk of fraud and breach of contract. As mentioned above, smart contract is based on the logic: "if this, then that", and executed via a mechanism which applies the terms of the contract automatically when terms embedded in smart contract's code are fulfilled. Moreover, the execution of smart contract does not require involvement of any third party or any specific approval, it's executed exactly the way it was codified. The feature of self-enforceability of smart contract challenges present legal system. It appears that not every single clause could be coded into the smart contract without reservation. Having regard to the nature of smart contracts, it shall be considered whether embedding the right to withdraw from contract or partial non-performance clause would be effective. Furthermore, it may be questionable whether smart contract correctly applies the interpretation clause, e.g. smart contract's software could not interpret if a contracting party exercised due diligence or acted in good faith. The effectiveness of smart contracts in given factual circumstances depends on the knowledge of legal experts with respect to specific characteristics of smart contracts themselves. Furthermore, there should be implemented mechanisms allowing every single smart contract to be amended, suspended or terminated by either the parties to such smart contract or by the judge submitted with case regarding any dispute or controversy arising out of such smart contract or in connection therewith.

\section{REFERENCES}

Christidis K., Devetsikiotis M., 2016, Blockchain and smart contracts for the Internet of Things. IEEE Access 4 (2016). 
Distributed Ledger Technology: beyond block chain. A raport by the UK Government Chief Scientific Adviser, https://assets.publishing.service.gov.uk/government/uploads/system/uploads/attachment_data/file/492972/gs-16-1-distributed-ledger-technology.pdf.

Derungs L.E., Küng Ch. ed., 2018, Data, Blockchain and Smart Contracts Proposal for a robust and forward-looking Swiss ecosystem, Regulatory Task Force Report Swiss LegalTech Association (SLTA), 27 April 2018, p. 42, https://www.swisslegaltech.ch/wp-content/uploads/2018/05/SLTA-Regulatory-Task-Force-Report-2.pdf.

Durovic M., Janssen A., The Formation of Smart Contracts and Beyond: Shaking the Fundamentals of Contract Law?, In: Smart Contracts and Blockchain Technology: Role of Contract Law", (L. DiMatteo, M. Cannarsa \& C. Poncibo eds Cambridge University Press 2019) (forthcoming), https://www.researchgate.net/publication/327732779.

Essebier J., Wyss D.A., 2017, Von der Blockchain zu Smart Contracts, In: Jusletter, 24 April 2017,https://www.vischer.com/fileadmin/redaktion/Dokumente/publikationen/fachpublikationen/JES_DOWY_Jusletter_Blockchain_04_2017.pdf.

Furrer A., 2018, The embedding of smart contracts into Swiss Private Law, https:// www.mme.ch/fileadmin/files/documents/MME_Compact/2018/1803_ Smart_Contracts_Furrer.PDF.

Gniewek E., Machnikowski P. ed., 2016, In: Kodeks cywilny. Komentarz, wyd. 7 , Warszawa.

Guarnizo J., Szalachowski P., 2018, PDFS: Practical Data Feed Service for Smart Contracts, https://arxiv.org/pdf/1808.06641.pdf.

Gupta S., 2018, The Management Accountant. The Journal for CMAs. Block chain Technology, June 2018, Vol 53, No 6, http://icmai.in/upload/Institute/ Journal/Journal_June_2018.pdf.

Hu Y., Liyanage M., Manzoor A., Thilakarathna K., Jourjon G., Seneviratne A., Ylianttila M., 2018, The Use of Smart Contracts and Challenges, 26 Sep 2018, https://www.researchgate.net/publication/328230865.

Hulicki M., Lustofin P., 2017, Wykorzystanie koncepcji blockchain w realizacji zobowiązań umownych, In: Człowiek w cyberprzestrzeni Nr 1/2017.

Idelberger F., Governatori G., Riveret R., Sartor G., 2016, Evaluation of logic-based smart contracts for blockchain systems. In: International Symposium on Rules and Rule Markup Languages for the Semantic Web. Springer. Jaccard G.O.B., 2017, Smart Contracts and the Role of Law, In: Jusletter IT, 23 November, https://papers.ssrn.com/sol3/papers.cfm?abstract_id=3099885. 
Kocot W. J. 2017, Kontrakty kreatywne - nowy rozdział w cyberrewolucji prawa umów, In: Experientia docet. Księga jubileuszowa ofiarowana Pani Profesor Elżbiecie Traple, ed. Kostański P., Podrecki P., Targosz T., Warszawa.

Kólvart M., Poola M., Rull A., 2016, Smart Contracts, In: The Future of Law and eTechnologies, ed. Kerikmäe T., Rull A., Springer.

Lauslahti K., Mattila J. \& Seppälä T., 2017, Smart Contracts - How will Blockchain Technology Affect Contractual Practices?, ETLA Reports, January 2017, No 68, https://pub.etla.fi/ETLA-Raportit-Reports-68.pdf.

Luu L., Chu D. H., Olickel H., Saxena P., Hobor A., Making smart contracts smarter. In Proceedings of the 2016 ACM SIGSAC Conference on Computer and Communications Security. ACM.

Schneider L., Evans J., Kim A., 2018, Why blockchain smart contracts matter. International Financial Law Review, London (Feb 27, 2018), https://search. proquest.com/docview/2020422359?accountid $=11796$.

Shcherbak S., Integrating Computer Science into Legal Discipline: The Rise of Legal Programming (September 14, 2014); December 18, 2018, https://papers.ssrn.com/sol3/papers.cfm?abstract_id=2496094.

Szabo N., 1997, Formalizing and Securing Relationship on Public Networks, First Monday Peer-Reviewed Journal on the Internet, Vol. 2, No 9, https:// firstmonday.org/article/view/548/469.

Szostek D., 2018, Blockchain a prawo, Warszawa, C.H. Beck.

Trüeb H. R., 2018, Smart Contracts, In: Festschrift für Anton K. Schnyder, eds. Pascal Grolimund Alfred Koller Leander D. Loacker Wolfgang Portmann.

Weber R. H. , 2018, "Rose is a rose is a rose is a rose"- what about code and law?, Computer Law \& Security Review 34.

Wolter A., Ignatowicz J., Stefaniuk K. ed., 2001, Prawo cywilne. Zarys części ogólnej, Warszawa.

Zacharzewski K., Piech K. ed., 2017, Przegląd polskiego prawa w kontekście zastosowań technologii rozproszonych rejestrów oraz walut cyfrowych. Stanowisko Strumienia w sprawie kierunków ewentualnych prac legislacyjnych oraz działań regulacyjnych instytucji publicznych, https://www.gov. pl/documents/31305/52168/przeglad_polskiego_prawa_w_kontekscie_zastosowan_technologii_rozproszonych_rejestrow_oraz_walut_cyfrowych.pdf/ f6e74ce0-09e5-776d-bd3b-c21fca96cce2. 